\title{
WATER-YIELD RELATIONSHIPS OF POTATO UNDER DIFFERENT IRRIGATION METHODS AND REGIMENS
}

\author{
Tolga Erdem*; Yesim Erdem; Halim Orta; Hakan Okursoy \\ University of Trakya - Faculty of Tekirdag Agriculture - Dept. of Farm Structures and Irrigation, 59030 - \\ Tekirdag - Turkey. \\ *Corresponding author <terdem@tu.tzf.edu.tr>
}

\begin{abstract}
Yield response to irrigation of different crops is of major importance in production planning where water resources are limited. This study aims to determine the effect of different irrigation methods and irrigation regimens on potato yield in the Trakya Region, Turkey, during 2003 and 2005. Potato was grown under furrow and drip irrigation methods and three regimens: irrigation applied when 30, 50, or $70 \%$ of the available water was consumed. The seasonal potato evapotranspiration ranged on 501 to 683 $\mathrm{mm}$ in 2003, and 464 to $647 \mathrm{~mm}$ in 2005. The furrow and drip irrigation methods had no significant effect on tuber yield for both years. Irrigation regimens influenced tuber yield $(P<0.05)$ in 2005 , and the highest tuber yield was registered for $30 \%$ irrigation regimen, reaching $35.13 \mathrm{t} \mathrm{ha}^{-1}$ in 2003 , and $44.56 \mathrm{t} \mathrm{ha}^{-1}$ in 2005. Water use efficiency values increased from 4.70 to $6.63 \mathrm{~kg} \mathrm{~m}^{-3}$ for furrow-irrigated treatments, and from 5.19 to $9.47 \mathrm{~kg} \mathrm{~m}^{-3}$ for drip-irrigated treatments.
\end{abstract}

Key words: furrow irrigation, drip irrigation, evapotranspiration, water use efficiency

\section{RELAÇÃO ÁGUA-PRODUÇÃO NA CULTURA DA BATATA SOB DIFERENTES MÉTODOS E REGIMES DE IRRIGAÇÃO}

\begin{abstract}
RESUMO: Em casos de limitações de recursos hídricos, o planejamento da produção agrícola depende da resposta dos parâmetros de produção à prática da irrigação. Este estudo visa determinar o efeito de diferentes métodos e regimes de irrigação na produtividade da batata na região de Trakya, Turquia, durante os anos de 2003 e 2005. As batatas foram plantadas sob irrigação por sulcos e por gotejamento, em três regimes: prática de irrigação quando 30,50 ou $70 \%$ da água disponível era consumida. A evapotranpisração sazonal da cultura variou entre 501 e 683 mm em 2003, e entre 464 e 647 mm em 2005. O método de irrigação não afetou significativamente a produção de tubérculos nos dois anos. Os regimes de irrigação influenciaram a produção de tubérculos $(P<0,05)$ em 2005, e as maiores produções foram registradas para o regime de irrigação $30 \%, 33,15 \mathrm{t} \mathrm{ha}^{-1}$ em 2003 e $44.56 \mathrm{t} \mathrm{ha}^{-1}$ em 2005. Os valores de eficiência do uso da água aumentaram de 4,70 para 6,63 nos tratamentos de irrigação por sulcos e de 5,19 para $9,47 \mathrm{~kg} \mathrm{~m}^{-3}$ nos tratamentos por gotejamento.

Palavras chave: irrigação por sulcos, gotejamento, evapotranspiração, eficiência hídrica
\end{abstract}

\section{INTRODUCTION}

Production of potato (Solanum tuberosum L.) takes a very important place in world agriculture, with a production potential of about 327 million t harvested and 18.6 million ha planted area (FAO, 2004). Potato is one of the main crops in Turkey where the production is about 4.80 million $\mathrm{t}$ harvested from 0.2 million ha (FAO, 2004). Early studies have shown that water is the most important limiting factor for potato production and it is possible to increase production levels by well-scheduled irrigation programs throughout the growing season (Boujelben et al., 2001; Deblonde \& Ledent, 2001; Faberio et al., 2001; Chowdhury et al., 2001; Panigrahi et al., 2001; Ferreira \& Carr, 2002; Kashyap \& Panda, 2003;
Shock et al., 2003; Yuan et al., 2003; Onder et al., 2005).

The Trakya region, Turkey, lies within a semiarid area with annual rainfall of about $575 \mathrm{~mm}$. From April to October the rainfall reaches $175 \mathrm{~mm}$, accounting for $30 \%$ of the annual precipitation. Water shortage in this season unfavors agricultural production, since the potato growing season goes from April to August. Therefore, because average rainfall and water resources are limited in this period, research on the relationships among yield, crop water consumption, and crop water stress is of great importance for developing water-sparing agricultural practices.

The aim of this research was determining the effects of furrow and drip irrigation methods under dif- 
ferent irrigation regimens on potato yield and yield components for these conditions.

\section{MATERIAL AND METHODS}

Field experiments on potato were carried out in 2003 and 2005 during the growing season (April to August) in Tekirdag, Turkey (40 $59^{\prime} \mathrm{N}, 2^{\circ} 29^{\prime} \mathrm{E}$; altitude, $4 \mathrm{~m}$ ), a semi-arid climatic region. Averages of annual temperature, relative humidity, wind speed, sunshine duration, and total annual precipitation are $13.8^{\circ} \mathrm{C}, 76 \%, 3.1 \mathrm{~m} \mathrm{~s}^{-1}, 6.5 \mathrm{~h}$, and $575.4 \mathrm{~mm}$, respectively (Orta et al., 2003). Climatic factors of the 2003 and 2005 growing seasons are listed in Table 1.

Chemical and physical properties of the experimental field soil related to irrigation are shown in Tables 2 and 3. The soil is generally deep, heavily textured, and well drained. The available water holding capacity within the $0.90 \mathrm{~m}$ soil profile is approximately $0.175 \mathrm{~m}$. There are no salinity and alkalinity problems. Electrical conductivity (EC) of the irrigation water is $0.42 \mathrm{dS} \mathrm{m}^{-1}$ and the sodium absorption ratio (SAR) is 2.7, classified as $\mathrm{C}_{2} \mathrm{~S}_{1}$ (Richards, 1954).
Selected, pre-sprouted potato tubers (Solanum tuberosum L. cv. Satina) were transplanted manually, at a depth of 10-12 cm on April 11, 2003, and April 15, 2005, and harvested respectively on August 8, 2003, and August 6, 2005. Fertilizer applications were based on soil test data (Table 2); a composed fertilizer including $60 \mathrm{~kg} \mathrm{ha}^{-1} \mathrm{~N}$ and $60 \mathrm{~kg} \mathrm{ha}^{-1} \mathrm{P}_{2} \mathrm{O}_{5}$ was utilized. Herbicides and insecticides were applied at ploughing to each plot when necessary. The preceding crop in both years was wheat.

The experiment was arranged in a split-plot design, with two irrigation methods as main plots and three irrigation regimens as subplots. Experimental plots measured $10.50 \mathrm{~m}^{2}(3.50 \times 3.00 \mathrm{~m})$ and contained 50 plants spaced $0.70 \times 0.30 \mathrm{~m}$. Plots were separated $3 \mathrm{~m}$ from each other.

Irrigation treatments were established to refill a $0.6 \mathrm{~m}$ depth-rooting zone as follows:

(i) irrigation methods - furrow irrigation (F) and drip irrigation (D); (ii) irrigation regimens - irrigation when $30 \%$ of the available water was consumed (IR1), irrigation when $50 \%$ of the available water was consumed (IR2), and irrigation when $70 \%$ of the avail-

Table 1- Some climatic parameters of region for the experimental years.

\begin{tabular}{|c|c|c|c|c|c|c|}
\hline Year & Month & $\begin{array}{c}\text { Average relative } \\
\text { humidity }\end{array}$ & $\begin{array}{c}\text { Average relative } \\
\text { humidity }\end{array}$ & $\begin{array}{c}\text { Average wind } \\
\text { speed }\end{array}$ & $\begin{array}{c}\text { Average sunshine } \\
\text { duration }\end{array}$ & Rainfall \\
\hline & & ${ }^{\circ} \mathrm{C}$ & $\%$ & $\mathrm{~m} \mathrm{~s}^{-1}$ & $\mathrm{~h}$ & $\mathrm{~mm}$ \\
\hline \multirow[t]{5}{*}{2003} & April & 8.8 & 80 & 2.2 & 6.3 & 27.2 \\
\hline & May & 17.9 & 76 & 2.0 & 9.5 & 5.0 \\
\hline & June & 23.0 & 70 & 2.3 & 10.9 & 1.4 \\
\hline & July & 24.8 & 70 & 2.6 & 10.7 & 15.8 \\
\hline & August & 25.2 & 69 & 2.6 & 11.0 & 0.4 \\
\hline \multirow[t]{5}{*}{2005} & April & 12.2 & 76 & 2.5 & 7.4 & 12.7 \\
\hline & May & 17.6 & 86 & 2.1 & 7.4 & 78.2 \\
\hline & June & 20.5 & 77 & 2.2 & 11.1 & 13.0 \\
\hline & July & 25.3 & 77 & 2.6 & 10.4 & 6.8 \\
\hline & August & 26.2 & 80 & 2.5 & 9.9 & - \\
\hline
\end{tabular}

Table 2 - Some chemical characteristics of the soil at the experimental site.

\begin{tabular}{lcccccc}
\hline Soil depth & Total salt & $\mathrm{pH}$ & $\mathrm{CaCO}_{3}$ & $\mathrm{P}_{2} \mathrm{O}_{5}$ & $\mathrm{~K}_{2} 0$ & Organic matter \\
\hline $\mathrm{cm}$ & $\%$ & & $\%$ & $--1.8-1.8$ & $\%$ \\
$0-20$ & 0.071 & 7.8 & 2.82 & 64.9 & 820 & 1.87 \\
$20-40$ & 0.077 & 7.8 & 3.35 & 47.4 & 515 & 1.24 \\
\hline
\end{tabular}

Table 3 - Some physical characteristics of the soil at the experimental site.

\begin{tabular}{|c|c|c|c|c|}
\hline Soil depth & Bulk density & Field capacity & Wilting point & Available water \\
\hline $\mathrm{cm}$ & $\mathrm{g} \mathrm{cm}^{-3}$ & \multicolumn{2}{|c|}{------- \% } & $\mathrm{mm} / 30 \mathrm{~cm}$ \\
\hline $0-30$ & 1.46 & 28.69 & 15.90 & 56.0 \\
\hline $30-60$ & 1.53 & 28.88 & 15.63 & 60.8 \\
\hline $60-90$ & 1.58 & 26.97 & 14.74 & 58.0 \\
\hline
\end{tabular}


able water was consumed (IR3). Level furrows were created between rows to ensure uniform water distribution in plots irrigated by furrow. Furrows were closed at the end to prevent runoff and a flow meter was used to measure the amounts of applied water. Drip irrigation was performed through pressure-compensating drippers, with $4 \mathrm{~L} \mathrm{~h}^{-1}$ flow in one lateral line per row; dripper and lateral spacings were 0.50 and $1.20 \mathrm{~m}$, depending on soil characteristics. The percentage of wetted area $(\mathrm{P})$ that relates dripper spacing to lateral spacing was determined as $71 \%$ (Keller \& Bliesner, 1990).

Soil water was monitored in each plot using a neutron probe (CPN, 503 DR Hydroprobe) for each $0.30 \mathrm{~m}$ soil layer during the whole growing season. The soil moisture content of the top $0.30 \mathrm{~m}$ was measured by the gravimetric method (Evett et al., 1993). The amount of soil water in the $0.60 \mathrm{~m}$ top layer was used to initiate irrigation. The crop water use (evapotranspiration) for ten-day periods was calculated applying the water balance method to the upper $0.90 \mathrm{~m}$ soil layer. Evapotranspiration (ET) was calculated using the soil water balance method (Heerman, 1985);

$$
\mathrm{ET}=\mathrm{P}+\mathrm{I}-\mathrm{D} \pm \Delta \mathrm{W}
$$

where $\mathrm{P}$ is the rainfall $(\mathrm{mm})$; $\mathrm{I}$ is the irrigation applied to individual plots $(\mathrm{mm})$; $\mathrm{D}$ is the deep percolation; and $\Delta \mathrm{W}$ is the change in water storage of the soil profile $(\mathrm{mm})$. Since the amount of irrigation water was only sufficient to bring the water deficit to field capacity, deep percolation was ignored.

Water use efficiency (WUE) for each treatment was calculated as tuber yield divided by seasonal evapotranspiration (ET). Irrigation water use efficiency (IWUE) was determined as (Zhang et al., 1999):

$$
\operatorname{IWUE}=\frac{\left(\mathrm{Y}_{1}-\mathrm{Y}_{\mathrm{NI}}\right)}{\mathrm{I}}
$$

where, $Y_{1}$ is the tuber yield of irrigation treatments $\left(\mathrm{t} \mathrm{ha}{ }^{-1}\right) ; \mathrm{Y}_{\mathrm{N}}$ is the tuber yield of non-irrigation treatment $\left(\mathrm{t} \mathrm{ha} \mathrm{a}^{-1}\right)$; and $\mathrm{I}$ is the amount of irrigation water (mm).

Data on effects of treatments on the yield and yield components were submitted to analysis of variance (ANOVA). The Least Significant Difference Test (LSD) was used to compare and rank treatments (Gomez \& Gomez, 1984).

\section{RESULTS AND DISCUSSION}

\section{Seasonal ET}

Data on the amounts of applied irrigation water and measured seasonal evapotranspiration for all treatments during the growing period are presented in Table 4. The number of irrigations events varied from 7 to 16 in 2003, and from 5 to 10 in 2005. The number of irrigations and the total applied irrigation water in 2005 growing season were smaller than in 2003 because of the higher rainfall. As expected, the drip-irrigated treatments required less water than the furrow-irrigated treatments, in both years. Among the irrigation regimens, the number of irrigations and the total applied irrigation water increased with irrigation when $30 \%$ of the available water was consumed, along with a decrease in the amount of water per irrigation event.

The seasonal (ET) is also shown in Table 4 and Figures 1 and 2. ET values for all treatments were close in both years, that of the first year being slightly higher. This may be attributed to differences in climatic conditions, planting date and total growing sea-

\begin{tabular}{|c|c|c|c|c|c|c|c|}
\hline Year & $\begin{array}{c}\text { Irrigation } \\
\text { method }\end{array}$ & $\begin{array}{l}\text { Irrigation } \\
\text { regimen }\end{array}$ & $\begin{array}{l}\text { Number of } \\
\text { irrigations }\end{array}$ & $\begin{array}{l}\text { Soil water } \\
\text { depletion }\end{array}$ & Rainfall & $\begin{array}{c}\text { Irrigation } \\
\text { water applied }\end{array}$ & $\begin{array}{c}\text { Seasonal } \\
\text { evapotranspiration }\end{array}$ \\
\hline \multirow[t]{6}{*}{2003} & Furrow & $30 \%$ & 14 & 57 & 50 & 576 & 683 \\
\hline & & $50 \%$ & 9 & 69 & 50 & 554 & 673 \\
\hline & & $70 \%$ & 7 & 57 & 50 & 537 & 644 \\
\hline & Drip & $30 \%$ & 16 & 64 & 50 & 469 & 583 \\
\hline & & $50 \%$ & 10 & 57 & 50 & 417 & 524 \\
\hline & & $70 \%$ & 7 & 56 & 50 & 395 & 501 \\
\hline \multirow[t]{6}{*}{2005} & Furrow & $30 \%$ & 10 & 58 & 111 & 478 & 647 \\
\hline & & $50 \%$ & 7 & 78 & 111 & 451 & 640 \\
\hline & & $70 \%$ & 5 & 82 & 111 & 403 & 596 \\
\hline & Drip & $30 \%$ & 10 & 38 & 111 & 339 & 488 \\
\hline & & $50 \%$ & 7 & 48 & 111 & 314 & 473 \\
\hline & & $70 \%$ & 5 & 60 & 111 & 293 & 464 \\
\hline
\end{tabular}

Table 4 - Amounts of irrigation water, rainfall and seasonal evapotranspiration. 


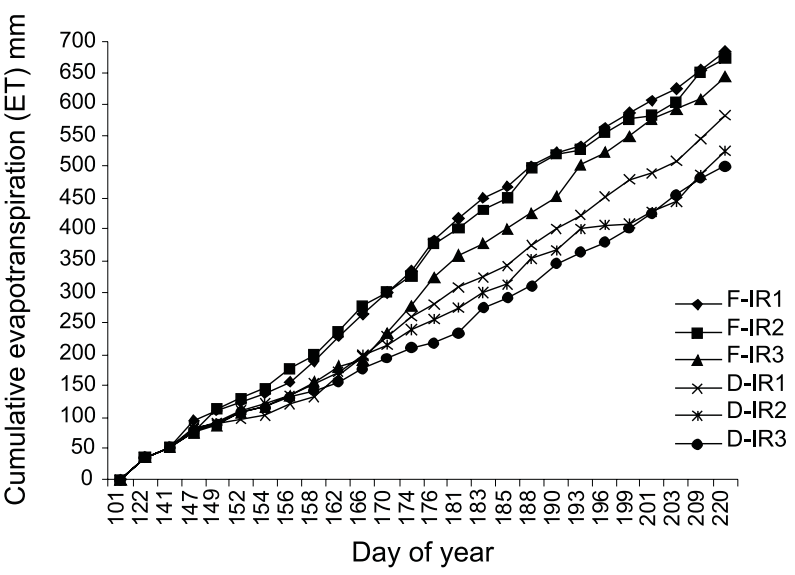

Figure 1 - Cumulative seasonal evapotranspiration in 2003.

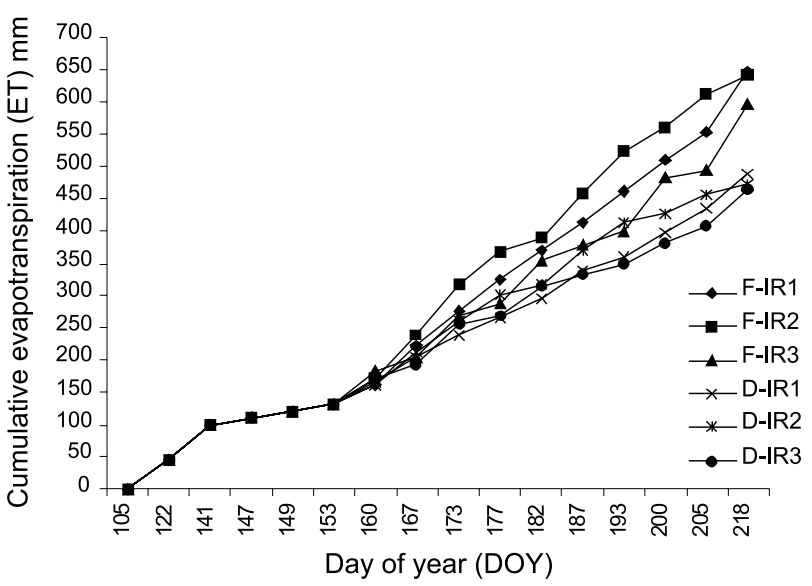

Figure 2 - Cumulative seasonal evapotranspiration in 2005. son irrigation depth. Figures 1 and 2 show the cumulative seasonal evapotranspiration of potato for all treatments under the furrow irrigation method and 30\% irrigation regimen. The furrow irrigation treatments consumed more water than drip irrigation treatments. The highest seasonal evapotranspiration was measured for the $30 \%$ irrigation regimen treatment (F-IR1 and D-IR2): $683 \mathrm{~mm}$ in 2003 and $647 \mathrm{~mm}$ in 2005 for the furrow irrigation. and $583 \mathrm{~mm}$ in 2003 and $488 \mathrm{~mm}$ in 2005 for drip irrigation. Early research reports that seasonal potato ET ranged from 350 to $800 \mathrm{~mm}$ for different climatic and environmental conditions (Doorenbos \& Kassam, 1979; Fabeiro et al., 2001; Panigrahi et al., 2001; Ferreira \& Carr, 2002; Shock et al., 2003; Onder et al., 2005).

\section{Tuber yield and yield components}

Tuber yield, plant height and yield components tuber size, tuber height, tuber weight, and tuber number per plant, monitored during both years for each treatment are listed in Tables 5 and 6 . The furrow and drip irrigation methods had no effect $(P<0.05)$ on tuber yield for both years. Statistical analyses for irrigation regimens on tuber yield differed between years $(P<0.05)$. While no differences were registered in $2003(P>0.05)$ irrigation regimens affected tuber yield $(P<0.05)$ in 2005 , and the highest tuber yield was obtained in the $30 \%$ irrigation regimen $-35.13 \mathrm{t} \mathrm{ha}^{-1}$ in 2003 , and $44.56 \mathrm{tha}^{-1}$ in 2005. The highest tuber yield was registered for the drip-irrigated treatment, watered

Table 5 - Effects of irrigation methods and irrigation regimens on potato yield and yield components in 2003.

\begin{tabular}{|c|c|c|c|c|c|c|c|}
\hline \multicolumn{2}{|l|}{ Treatments } & \multirow{2}{*}{ Plant height } & \multirow{2}{*}{ Tuber size } & \multirow{2}{*}{ Tuber height } & \multirow{2}{*}{$\begin{array}{c}\text { Tuber weight } \\
\mathrm{g}\end{array}$} & \multirow{2}{*}{ Tuber number per plant } & \multirow{2}{*}{$\frac{\text { TuberYielc }}{\mathrm{t} \mathrm{ha}^{-1}}$} \\
\hline & & & & & & & \\
\hline \multicolumn{8}{|c|}{ Irrigation method } \\
\hline & Furrow & 93.8 & 5.7 & 6.8 & 133.4 & 6.2 & 32.23 \\
\hline & Drip & 93.4 & 5.7 & 6.8 & 134.1 & 5.8 & 30.60 \\
\hline & $\operatorname{LSD}(5 \%)$ & ns & ns & ns & ns & ns & ns \\
\hline \multicolumn{8}{|c|}{ Irrigation regimen } \\
\hline & $30 \%$ & 94.6 & 5.5 & 7.1 & 135.5 & 6.8 & 35.13 \\
\hline & $50 \%$ & 90.0 & 5.8 & 6.5 & 127.7 & 5.6 & 29.39 \\
\hline & $70 \%$ & 96.2 & 5.9 & 6.9 & 138.2 & 5.8 & 29.75 \\
\hline & $\operatorname{LSD}(5 \%)$ & ns & ns & ns & ns & ns & ns \\
\hline \multicolumn{8}{|c|}{ Irrigation method $\times$ irrigation regimen interactions } \\
\hline \multirow[t]{3}{*}{ Furrow } & $30 \%$ & 98.8 & 5.3 & 7.3 & 143.8 & 7.3 & 34.44 \\
\hline & $50 \%$ & 86.8 & 5.8 & 6.4 & 125.0 & 5.9 & 31.59 \\
\hline & $70 \%$ & 95.8 & 6.0 & 6.7 & 131.5 & 5.5 & 30.67 \\
\hline \multirow[t]{4}{*}{ Drip } & $30 \%$ & 90.4 & 5.6 & 6.8 & 127.1 & 6.2 & 35.81 \\
\hline & $50 \%$ & 93.2 & 5.8 & 6.6 & 130.3 & 5.2 & 27.18 \\
\hline & $70 \%$ & 96.5 & 5.7 & 7.0 & 144.9 & 6.0 & 28.82 \\
\hline & LSD (5\%) & ns & ns & ns & ns & ns & ns \\
\hline
\end{tabular}


when $30 \%$ of the available water was consumed. The observed yield and water use relationship on potato was similar to that reported in previous investigations. Faberio et al. (2001), in Spain, found that $597 \mathrm{~mm}$ irrigation water was required to reach maximum tuber yield $45.18 \mathrm{t} \mathrm{ha}^{-1}$; Onder et al. (2005) determined that surface drip irrigation and subsurface drip irrigation methods did not significantly affect tuber yield under Turkey soil/climate conditions. Other researchers have also reported increased tuber yield with irrigation applications (Shock et al., 1998; Ferreira \& Carr, 2002; Kashyap \& Panda, 2003; Yuan et al., 2003; Kang et al., 2004).

The yield characteristics were not affected by irrigation methods and irrigation regimens treatments $(P>0.05)$, although drip-irrigated treatments yielded generally higher values than furrow-irrigated treatments. The tuber number per plant increased from 5.5 to 7.3 in 2003, and from 5.6 to 6.5 in 2005 . Similarity, Onder et al. (2005) reported that the number of tuber per plant was not significantly affected by irrigation methods. The highest values of tuber weight were recorded for the drip irrigation treatment.

\section{Water use efficiency}

Data on irrigation water use efficiency (IWUE) and water use efficiency (WUE) for both years are presented in Table 7. Although tuber yield was about the same, the furrow irrigation method used higher amounts of water than drip irrigation methods (Table 3). IWUE of drip-irrigated treatments were higher and differed from furrow-irrigated treatments in the second year $(P<0.05)$. However, the IWUE did not differ $(P>0.05)$ for irrigation regimen and irrigation method $\times$ irrigation regimen interactions. The drip-irrigated treatments produced higher WUE in comparison to furrow-irrigated treatments in $2005(P<0.05)$. WUE of potato was also found not to be significantly different for irrigation regimen and irrigation method $\times$ irrigation regimen interaction. Among the irrigation regimens, the highest WUE were generally obtained from application of irrigation when $30 \%$ of the available water was consumed. Kang et al. (2004) and Onder et al. (2005) also registered similar WUE values for potato.

The seasonal evapotranspiration presented peaks of $683 \mathrm{~mm}$ (2003) and $647 \mathrm{~mm}$ (2005) under furrow irrigation method, with irrigation when $30 \%$ of the available water was consumed. Irrigation regimens affected tuber yield $(P<0.05)$ in the second year, but tuber yield was not affected $(P<0.05)$ by the irrigation method. Different irrigation treatments did not result in significant difference on yield parameters. Drip irrigation method yielded higher values of IWUE and WUE, since drip irrigation consumed less water than furrow irrigation.

Table 6 - Effects of irrigation methods and irrigation regimens on potato yield and yield components in 2005 .

\begin{tabular}{|c|c|c|c|c|c|c|c|}
\hline & Treatments & Plant height & Tuber size & Tuber height & Tuber weight & Tuber number per plant & TuberYield \\
\hline & & $-\cdots-\cdots$ & $---\mathrm{cm}--$ & -1-n & $\mathrm{g}$ & & $\mathrm{t} \mathrm{ha}^{-1}$ \\
\hline \multicolumn{8}{|c|}{ Irrigation method } \\
\hline & Furrow & 94.4 & 6.2 & 7.4 & 159.0 & 6.0 & 38.30 \\
\hline & Drip & 94.1 & 6.5 & 7.5 & 166.0 & 6.0 & 43.25 \\
\hline & $\operatorname{LSD}(5 \%)$ & ns & ns & ns & ns & $\mathrm{ns}$ & ns \\
\hline \multicolumn{8}{|c|}{ Irrigation regimen } \\
\hline & $30 \%$ & 97.3 & 6.5 & 7.6 & 170.6 & 6.4 & $44.56 \mathrm{a}$ \\
\hline & $50 \%$ & 94.4 & 6.6 & 7.4 & 159.0 & 6.0 & $40.92 \mathrm{ab}$ \\
\hline & $70 \%$ & 91.2 & 5.9 & 7.4 & 158.0 & 5.8 & $36.85 \mathrm{abc}$ \\
\hline & $\operatorname{LSD}(5 \%)$ & ns & ns & ns & ns & ns & 4.9 \\
\hline \multicolumn{8}{|c|}{ Irrigation method $\mathrm{x}$ irrigation regimen interactions } \\
\hline \multirow[t]{3}{*}{ Furrow } & $30 \%$ & 99.3 & 6.6 & 7.6 & 168.8 & 6.5 & 42.92 \\
\hline & $50 \%$ & 92.7 & 6.0 & 7.2 & 150.9 & 6.0 & 37.19 \\
\hline & $70 \%$ & 91.2 & 6.0 & 7.4 & 157.3 & 5.6 & 34.78 \\
\hline \multirow[t]{4}{*}{ Drip } & $30 \%$ & 95.3 & 6.4 & 7.5 & 172.3 & 6.2 & 46.20 \\
\hline & $50 \%$ & 96.0 & 7.2 & 7.5 & 167.0 & 5.9 & 44.65 \\
\hline & $70 \%$ & 91.1 & 5.8 & 7.4 & 158.6 & 5.9 & 38.91 \\
\hline & LSD $(5 \%)$ & ns & ns & ns & ns & ns & ns \\
\hline
\end{tabular}


Table 7 - Irrigation water use efficiency (IWUE) and water use efficiency (WUE) for potato under different irrigation method and irrigation regime.

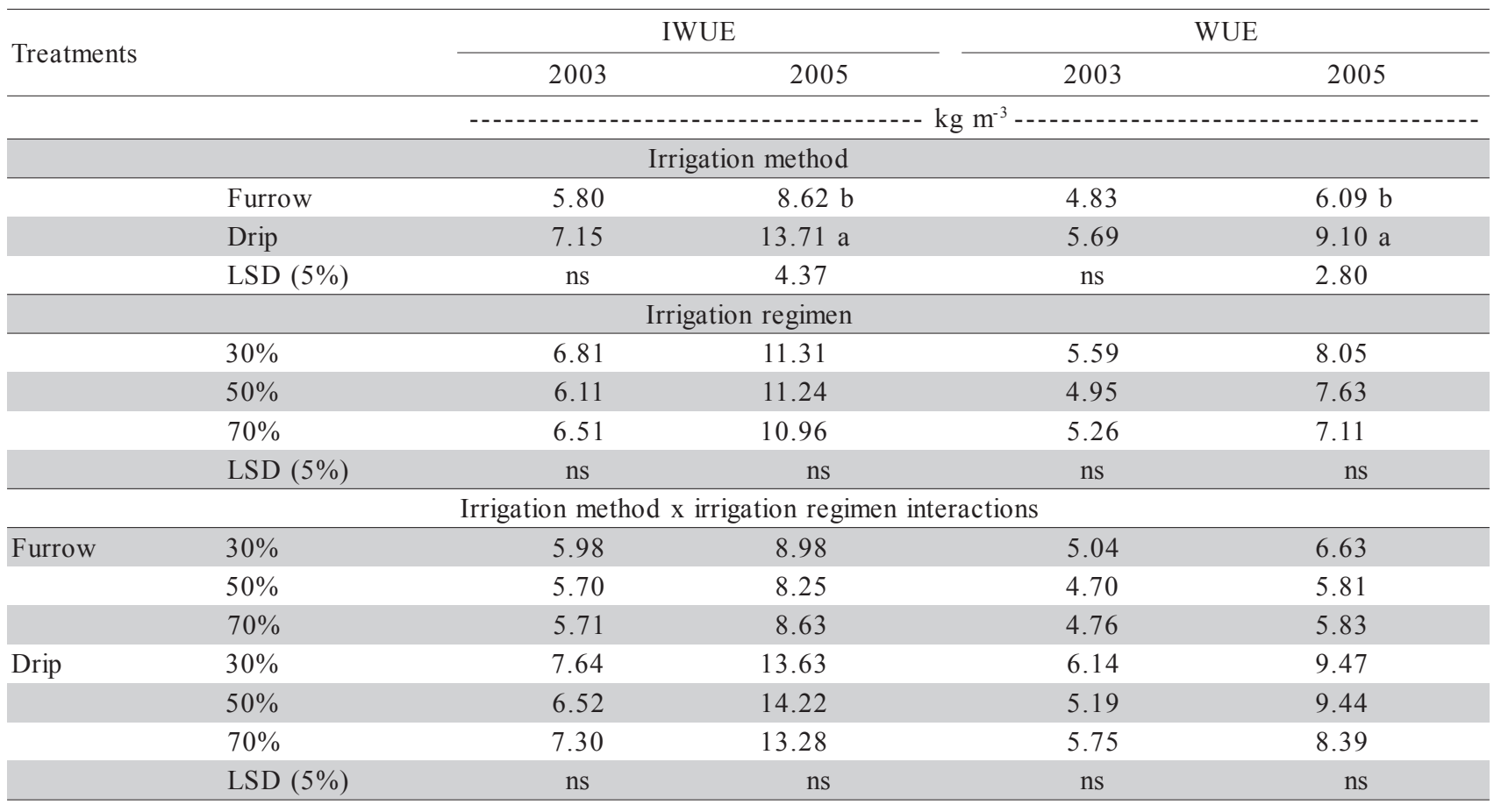

\section{ACKNOWLEDGEMENT}

To project TUBAP-537 supported by Trakya University Research Fund.

\section{REFERENCES}

BOUJELBEN, A.; MBAREK, K.B.; AID, A.B. Comparative study of the drip and furrow irrigation on seasonable potato crop. Tropicultura, v.19, p.110-115, 2001.

CHOWDHURY, S.R.; ANTONY, E.; SINGH, R.; THAKUR, A.K.; VERMA, H.N. Leaf area development and its relationship with tuber yield in sweet potato under different irrigation regimes. Orissa Journal of Horticulture, v.29, p.20-23, 2001.

DEBLONDE, P.M.K.; LEDENT, J.F. Effects of modarete drought conditions on green leaf number, stem height, leaf length and tuber yield of potato cultivars. European Journal of Agronomy, v.14, p.31-41, 2001.

DOORENBOS, J.; KASSAM, A.H. Yield response to water. Rome: FAO, 1979. 198p. (Irrigation and Drainage Paper, 3).

EVETT, S.; HOWELL, A.T.; STEINER, J.L.; CRESAP, L.L. Management of irrigation and drainage. Utah: Div/ASCE, 1993.

FABERIO, C.; OLALLA, F.M S.; JUAN, J.A. Yield size of deficit irrigated potatoes. Agriculture and Water Management, v.48, p.255-266, 2001

FAO. FAOSTAT. Agriculture. Rome, 2006. Available in: http:// faostat.fao.org/faostat/collections?subset=agriculture. Accessed at: June, 2004.

FERREIRA, T.C.; CARR, M.K.V. Response of potatoes (Solanum tuberosum L.) to irrigation and nitrogen in a hot, dry climate: I. Water use. Field Crops Research, v.78, p.51-64, 2002.

GOMEZ, K.A.; GOMEZ, A.A. Statistical procedures for agricultural research. New York: John Wiley \& Sons, 1984.

HEERMAN D.F. ET in irrigation management. In: NATIONAL CONFERENCE ON ADVANCES IN EVAPOTRANSPIRATION, Chicago, 1985. Proceedings. St. Joseph: ASAE, 1985. p.323-334,
KANG, Y.; WANG, F.X.; LIU, H.J.; YUAN, B.Z. Potato evapotranspiration and yield under different drip irrigation regimes. Irrigation Science, v.23, p.133-143, 2004.

KASHYAP, P.S.; PANDA, R.K. Effect of irrigation scheduling on potato crop parameters under water stressed conditions. Agriculture and Water Management, v.59, p.49-66, 2003.

KELLER, J.; BLIESNER. R.D. Sprinkle and trickle irrigation. New York: Van Nostrand Reinhold, 1990.

ONDER, S.; CALISKAN, M.E.; ONDER, D.; CALISKAN, S. Different irrigation methods and water stress effects on potato yield and yield components. Agriculture and Water Management, v.73, p.73-86, 2005.

ORTA, A.H.; ERDEM, Y.; ERDEM, T. Crop water stress index for watermelon. Scientia Horticulturae, v.98, p.121-130, 2003.

PANIGRAHI, B.; PANDA, S.N.; RAGHUWANSHI, N.S. Potato water use and yield under furrow irrigation. Irrigation Science, v.20, p.155163, 2001.

RICHARDS, L.A. Diagnosis and improvement of saline and alkali soils. Washington: USDA, 1954. (Agriculture Handbook, 60).

SHOCK, C.C.; FEIBERT, E.B.G.; SAUNDERS, L.D. Potato yield and quality response to deficit irrigation. Horticultural Science, v.33, p.655-659, 1998.

SHOCK, C.C.; FEIBERT, E.B.G.; SAUNDERS, L.D. 'Umatilla Russet' and 'Russet Legend' potato yield and quality response to irrigation. Horticultural Science, v.38, p.1117-1121, 2003.

YUAN, B.Z.; NISHIYAMA, S.; KANG, Y. Effects of different irrigation regimes on the growth and yield of drip-irrigated potato. Agriculture and Water Management, v.63, p.153-167, 2003.

ZHANG, H.; WANG, X.; YOU, M.; LIU, C. Water- yield relations and water-use efficiency of winter wheat in the North China Plain. Irrigation Science, v.19, p.37-45, 1999.

Received October 20, 2005

Accepted March 31, 2006 